International Journal of Current Advanced Research

ISSN: O: 2319-6475, ISSN: P: 2319 - 6505, Impact Factor: SJIF: 5.995

Available Online at www.journalijcar.org

Volume 6; Issue 4; May 2017; Page No. 3660-3661

DOI: http://dx.doi.org/10.24327/ijcar.2017.3661.0341



Research Article

\title{
PERCEPTION OF PAIN USING DIFFERENT SIZE OF NEEDLE GAUGES
}

\section{Valli B}

Saveetha University

\section{A R T I C L E I N F O}

Article History:

Received $18^{\text {th }}$ February, 2017

Received in revised form $12^{\text {th }}$ March, 2017

Accepted $26^{\text {th }}$ April, 2017

Published online $28^{\text {th }}$ May, 2017

\section{Key words:}

Pain, local anesthesia, needle gauge, dentistry, injection

\begin{abstract}
A B S T T R A C T
Since the inception of pain in, the field of dentistry has had the challenge of trying to render a painless experience for the patient. The fear of pain attributed to anesthetic needle injection has been stated as an obstacle in providing appropriate dental care. A variety of patient management techniques have been attempted to improve patient comfort during dental anesthetic administration, including but not limited to smaller gauge needle sizes, slow computer-regulated administration, distraction techniques, vibrating devices, and topical anaesthetics .
\end{abstract}

Copyright $(2017$ Valli B. This is an open access article distributed under the Creative Commons Attribution License, which permits unrestricted use, distribution, and reproduction in any medium, provided the original work is properly cited.

\section{INTRODUCTION}

Majority of patients have a fear of the anaesthetic injection and mostly associates dental treatment with pain. The pain associated is the first thing the patient thinks about when considering to undertake any dental care. The needle/pain is very influential in a patient's perception of the dental profession. According to the American Dental Association, fear of pain is a very important factor that stops patients from visiting their dentists. Various kinds of fear associated to previous clinical experience affect patients' attitude to local anaesthesia or dentist ${ }^{[1]}$.

Pain is explained to be an unpleasant sensation which ranges from mild discomfort to extreme agonizing distress that is correlated to causepotential damage to the tissue. And definitely it is multidimensional complex bio-psychosocial event that varies between every single individual ${ }^{[2]}$. Dental pain is considered to be one of the most important reason for an individual to visit an endodontist.

And almost all the major Endodontic treatments basically require the injection of local anesthesia. Pain in dental therapy is associated with both procedural pain and post operative pain. But the pain related to theendodontic treatment is overestimated. Most of the patients gets anxious during the Root canal treatment due the pain they expect they will undergo. Because of this anxiety and the added effects of inflammation, the threshold of pain gets decreased and thus it reduces the effect of $\mathrm{LA}^{[3]}$.

*Corresponding author: Valli B

Saveetha University
Although local anaesthesia techniques do not provide painfree treatment, this pain is generally tolerable. Pain can result from the mechanical trauma of needle introduction into the site of injection, or from the sudden distension of the tissues, resulting from a rapid discharge of the contents of the syringe. Pain can also be caused by the stimulation of the first few drops of the local anaesthetic ${ }^{[4,5]}$.

There are various methods to assess the level of pain ${ }^{[6-8]}$

1. Numeric Rating scale

2. Visual Analog scale

3. Wong- baker faces pain rating scale

4. Pain quality assessment scale

This analysis of pain perception becomes very important because when the people are asked to list the factors they feel is necessary to choose a dentist the two most important are:

1. a dentist who does not hurt and

2. a painless injection ${ }^{[9]}$.

The endodontic pain is mainly caused due to the inflammation of the pulp tissue occurring as a result of dental caries progressing deep into the tooth ${ }^{[10]}$. But, for painless dentistry to be developed successfully, local anestheticshas to be injected with the help of a cartridge, syringe, and needle. This causes the major problem of fear of needles which is also called as trypanophobia and its consequences like, the occurrence of syncope or any other medical emergency situationswhile injecting the local anesthetic agent. More than $50 \%$ of medical emergencies which happens in dental offices are either during or immediately following administration of a local anesthetic ${ }^{[11]}$. 
The needle gauges are available in various sizes like 20 size, 21 size, 22 size, 23 size, 26 size, 27 size, 30 size needles. Among these three random sized needles were chosen and used for the study .Successful local anesthesia is the bedrock of pain control in dentistry. Effective pain control is essential to reduce fear and anxiety associated with dental procedures $^{[12]}$

Thus, to identify the pain perceived by patients when given with three different sized needle and to vary the use of needle gauges according to the perception of minimum pain by the patients, this study was conducted.

\section{MATERIALS AND METHODS}

30 patients visiting a private dental college for root canal treatment for maxillary teeth were included for the study based on the inclusion criteria. 21,22,26 gauge needles were used for delivering the Local anaesthetic solution for infiltration. Patient were asked to rate their pain perception on Numeric Rating Scaling. Data collected were documented and statistical analysis were done.

Where in the groups allocated are as the follows

Group I- 26 gauge needle

Group II- 22 gauge needle

Group III- 21 gauge needle

Numeric Rating Scale Used In This Study



\section{RESULTS}

\begin{tabular}{cccc}
\hline & N & MEAN & STD Deviation \\
\hline Group I & 10 & 2.40 & 0.699 \\
Group II & 10 & 4.30 & 0.675 \\
Group III & 10 & 7.10 & 0.994 \\
Total & 30 & 4.60 & 2.111
\end{tabular}

\section{DISCUSSION}

On statistical analysis of the data it was found that the mean pain values of the groups I,II,III were $2.40,4.30$ and 7.10respectively. And the standard deviation values of the group I,II,III were found to be $0.699,0.675$ and 0.994 . Pain caused due to injections is because of the penetration of the needle into the skin and by the solution that is being deposited into target tissues ${ }^{[13]}$. From the values obtained it is evident that the needle with the maximum size causes least pain. This can be because of the fact that 26 gauge needle required less force when compared to 21 gauge needle. It can also be due to the fact that the larger size needles causes trauma to the soft tissue while perfusion whereas the smaller size needle causes more trauma which results in increased pain experienced by the patients.

\section{CONCLUSION}

The larger gauge needle group patients experienced least pain. many patients consider endodontic procedure to be more painful, by using a less painful injection we can reduce the anxiety levels of the patient and can improve the patient cooperation.

\section{References}

1. Milgrom P, Coldwell SE, Getz T, Weinstein P, Ramsey DS. Four dimensions of fear of dental injections. $J A m$ Dent Assoc. 1997; 128:756- 66.

2. Seensson P, Baad-Hansen L, Thygesen T, Juhl GI, Jensen TS Overview on tools and methods to assess neuropathic trigeminal pain. J Orofac Pain 2004 Fall; 18(4):332-338.

3. Walton RE, Torabinejad M. Managing local anesthesia problems in the endodontic patient. J Am DentAssoc 1992 May; 123(5):97-102.

4. Ballard BE. Biopharmaceutical considerations in subcutaneus and intramuscular drug administration. $J$ PharmSci. 1968; 57:357-78.

5. Keller BJ. Comparison of the effectiveness of two topical anesthetics and placebo in reducing injection pain. Hawaii Dent J. 1985; 16:10- 1.

6. Price DD, McGrath PA, Rafii A, Buckingham B. The validation of visual analogue scales as ratio scale measures for chronic and experimental pain. Pain. 1983;17:45-56. [PubMed]

7. Miller MD, Ferris DG. Measurement of subjective phenomena in primary care research: the visual analogue scale. Fam Pract Res J. 1993; 13:15-24. [PubMed]

8. Price DD, Bush FM, Long S, Harkins SW. A comparison of pain measurement characteristics of mechanical visual analogue and simple numerical rating scales. Pain. 1994; 56:217-226. [PubMed]

9. de St. Georges J. How dentists are judged by patients. Dent Today. 2004 23:96, 98-99. [PubMed]

10. Endodontic Pain - Cause And Management: A Review Nivethithan* and James D. Raj Department of Endodontics, Saveetha dental college, Chennai, Tamil Nadu, India

11. Malamed SF. Malamed SF. Handbook of Medical Emergencies. 6th ed. St Louis: The CV Mosby Co; 2007. Introduction. In.

12. Burns CA, Ferris G, Feng C, Cooper JZ, Brown MD. Decreasing the pain of local anesthesia: a prospective, double-blind comparison of buffered, premixed $1 \%$ lidocaine with epinephrine versus $1 \%$ lidocaine freshly mixed with epinephrine. J Am AcadDermatol. 2006; 51:128-131. [PubMed]

13. Lehtinen R. Penetration of 27-and 30-gauge dental needles. Int J Oral Surg 1983; 12:444-5. Back to cited text no. 10[PUBMED]

\section{How to cite this article:}

Valli B (2017) ' Perception Of Pain Using Different Size Of Needle Gauges', International Journal of Current Advanced

Research, 06(05), pp. 3660-3661.

DOI: http://dx.doi.org/10.24327/ijcar.2017.3661.0341 